\title{
KIILTOKUVAPOJISTA JA IHMISROSKISTA
}

Luca Tainio

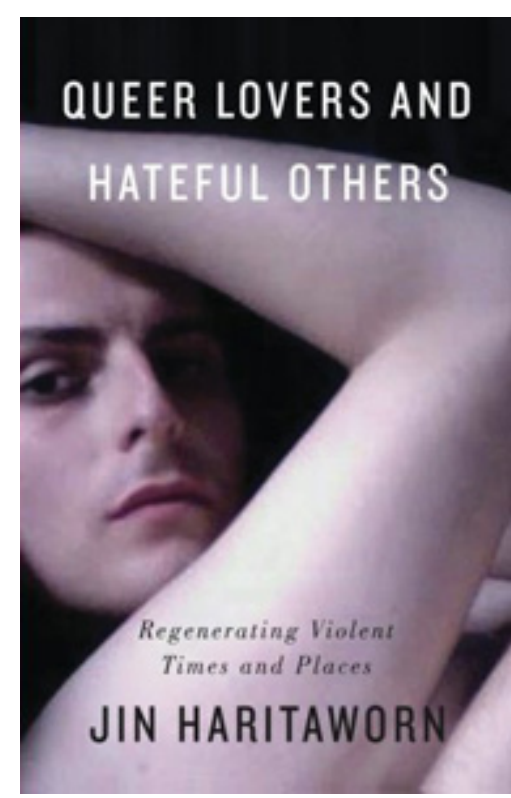

Jin Haritaworn. 2015. Queer Lovers and Hateful Others. Regenerating Violent Times and Places. Lontoo: PlutoPress, $203 \mathrm{~s}$.

Jin Haritaworn tarjoaa kirjassaan tarkkasilmäisen ja historiaan sidotun analyysin valkoisen, hyväksyttävän queerin hahmon syntymisestä rodullistettujen Toisten kustannuksella. Haritaworn käyttää esimerkkinään kolmen berliiniläisen kaupunginosan gentrifikaatioprosessia, eli perinteisten työväenluokkaisten alueiden keskiluokkaistumista niin sanotun luovan luokan muuton myötä. Luokan lisäksi Haritaworn painottaa rodun, sukupuolen ja seksuaalisuuden risteäviä merkityksiä. Hän tarkastelee prosesseja historiallisessa kolonialismin ja rodullistamisen kehyksessä, kyseenalaistaen ajatuksen liikkumisesta homofobisesta menneisyydestä kohti hyväksyvämpää ja tasa-arvoisempaa tulevaisuutta.

Haritaworn kirjoittaa pääasiallisesti berliiniläisten Schönebergin, Kreuzbergin ja Neuköllnin muutoksista jäljittäen eri kaupunginosien gentri- fikaatioprosessien kytköksiä näkemyksiin hyväksyttävistä kaupallisista queer-ruumiista ja niistä, joiden nähdään jarruttavan neoliberaalia kehitystä. Schöneberg on tunnettua homoaluetta (gayborhood), ja läheiset Kreuzberg ja Neukölln perinteisesti ei-valkoisten työläisten asuttamia naapurustoja, joista on muokkaantunut "trendikkäitä" asuinalueita valkoisten keskiluokkaisten queerien muuttaessa alueelle. Samalla kuitenkin alueella alun perin asuneet ovat löytäneet itsensä nousevien vuokrien, syrjinnän ja turistilaumojen keskeltä kilpailemasta tilasta, asunnoista - ja ihmisarvosta. Haritaworn alleviivaakin miten nimenomaan valkoiset normatiiviset homot on nähty alueiden arvoa mahdollisesti nostavina, samaistuttavina, oikealla tavalla haavoittuvina ja rakastavina. Haluttavuus noudattelee valkoisuuden, vammattomuuden, nuoruuden ja normatiivisen sukupuolen rajoja. Samanaikaisesti kyky vallata ja pitää tilaa niin symbolisesti kuin konkreettisestikin riippuu sekin pääsystä luokan, rodun ja sukupuolen tuomiin etuoikeuksiin sekä etäisyydestä niihin ruumiisiin ja tiloihin, jotka nähdään tuhottavina, vallattavina ja arvottomina.

\section{Rakastajista ja vihaajista}

Kirjan nimessä mainitusta queerin rakastajan hahmosta Haritaworn kirjoittaa käyttäen esimerkkinä queeria suudelmaa; mainoksissa, yhdenvertaisuusprojekteissa ja lehtijutuissa kierrätettävää kuvastoa suutelevista homomiehistä. Valkoisten ja treenattujen, sukupuoleltaan normatiivisten
Pervosilmäys Arvostelut

Arvostelut 
homomiesten väliset monogamiaan ja kunniallisuuteen sidotut julkiset hellyydenosoitukset ovat merkityksellistyneet suvaitsevaisuuden ja yhdenvertaisuuden symboleiksi. Haritawornin mukaan kuvastolla uudelleenkirjoitetaan väkivallan ja aids-kriisin värittämiä onnettomia loppuja normatiivisen romanttisen rakkaustarinan onnellisiksi lopuiksi. Kaikki suukot eivät kuitenkaan ole samanarvoisia. Haritaworn painottaakin kuinka tärkeää on nähdä mitä varten tiettyjä kuvastoja kierrätetään ja ketkä niistä hyötyvät. Kirjassa tehdään näkyväksi se prosessi, jolla tuo subjektius rakentuu rasistisille diskursseille homofobisista, vihamielisistä Toisista. Niin HLBTI-järjestöjen sisällä kuin julkisessa mediassakin kierrätetyt kuvastot romanttiseen rakkauteen viittaavista homosuukoista synnyttävät oikealla tavalla haavoittuvan ja suojelua kaipaavan queerin subjektin, joka ansaitsee homoystävällisen yhteisön tuen ja viranomaisten suojelua. Poliisit otetaan viharikosdiskurssin myötä mukaan projektiin, jossa väkivaltaiset, homofobiset Toiset uhkaavat ja tuottavat turvattomuutta valkoisille homoille. Haritaworn huomauttaa kuitenkin että todellisuudessa gentrifikaation myötä nimenomaan ei-valkoisten (queerien) asukkaiden yhteisöt kutistuvat ja hajoavat, mikä tuottaa turvattomuutta, jota poliisin läsnäolo vain lisää.

Queerin rakastajan lisäksi kirjan nimessä mainitaan vihamielinen Toinen. Tällä viitataan niihin rodullistettuihin, sukupuoleltaan ei-normatiivisiin, työväenluokkaisiin ja liian queereihin ruumiisiin, joilla ei ole pääsyä tuohon hyväksyttävällä tavalla haavoittuvaan ja suojeltavaan asemaan. "Ne" erotetaan "meistä", patologisoidaan, suljetaan laitoksiin, leimataan homofobisiksi ja vihamielisiksi. Viharikosdiskurssin ja moraalipaniikin lietsonnan avulla luodaan vastakkainasettelu, jossa eri ryhmien limittäisyys unohtuu. Vaikka Haritaworn kirjoittaa tiettyjen kaupunginosien ja historioiden kehyksessä, ovat nuo samat rasismin mekanismit tuttuja ja kivuliaan ajankohtaisia myös suomalaisessa kontekstissa. Mieleen nousee äärioikeistolaisen Finnish Defence Leaguen pyrkimykset osallistua Pirkanmaa Pride -kulkueeseen vastustaakseen "homofobista Islamia" vuonna 2012, minkä jälkeen turvapaikanhakijoiden leimaaminen konservatiivisiksi, patologisesti väkivaltaisiksi ja vähemmistöille vaarallisiksi on vain voimistunut julkisessa keskustelussa. Samaan aikaan queerit turvapaikanhakijat ovat yhä vain haavoittuvammassa asemassa - mutta eivät oikealla tavalla. Kuten Haritaworn kirjassaan argumentoi, rotu ja luokka merkityksellistyvät seksuaalisuutta (ja jossain määrin sukupuolta) tärkeämmiksi ominaisuuksiksi oikeanlaista queeria haavoittuvuutta rakennettaessa.

\section{Menneisyyden harhasta}

Paikkojen lisäksi Haritaworn liikkuu myös ajassa, tämän hetken ja menneisyyden välillä. Hän tekee mielenkiintoisia huomioita ja viittauksia varsinkin Saksan historiaan, holokaustin merkitykseen ja sen käsittelyyn nykypäivänä. Kirjassa yhtenä esimerkkinä käytetään Berliiniin pystytettyä muistomerkkiä keskitysleireillä kuolleiden (mies)homojen muistolle. Haritaworn käsittelee patsasta tapana sijoittaa fasistinen väkivalta menneisyyteen. Muistomerkki toimii oikeanlaisen valkoisen syyllisyyden osoittamisen paikkana ja välineenä, jonka avulla rasismin ja väkivallan saa sijoitettua pois tästä ajasta, pois "meistä". Tämä kuitenkin tarkoittaa kieltäytymistä näkemästä samoja rasistisia rakenteita nykypäivänä, sekä intersektionaalisuuden puuttumista puhuttaessa juutalaisten ja homojen vainoista ja näiden ryhmien muistamisesta sodan jälkeen. Antisemitismi (uudelleen)rakennetaan rodullistettujen ryhmien ominaisuudeksi. Haritaworn tekee samalla mielenkiintoisen huomion ajallisuudesta; kun tietyt kulttuurit ja uskonnot leimataan takaperoisiksi, ennakkoluuloisiksi ja sivistymättömiksi, "niiden" nykyisyys näyttäytyy "meidän" menneisyytenämme. Tämä johtaa Haritawornin mukaan valheelliseen queeriin nostalgiaan, kaipuuseen aikaan jolloin "niitä" (maahanmuuttajia) ei tietyillä alueilla vielä ollut. 
Haritaworn onnistuu tarjoamaan lukijalle sopivasti kontekstia ja taustatietoa, jotta historialliset ja nykypäivän yhteydet eivät jää epäselviksi tai epämääräisiksi. Monet kirjassa avatut historialliset kerrostumat jäisivät varmasti monelta lukijalta huomaamatta ellei Haritaworn kuljettaisi lukijaa sujuvasti tapahtumien ja diskurssien välillä. Väittäisin, että suuri osa varsinkin valkoisista länsimaalaisista lukijoista on tottunut tietynlaisiin valmiiksi muotoiltuihin, tietystä näkökulmasta esitettyihin historian kertomuksiin, joihin Haritaworn avaa uusia näkökulmia. Esimerkiksi huomiot psykologian, patologian ja eugeniikan yhteyksistä tietynlaisten rodullistettujen stereotypioiden syntymiseen olivat eräs mielenkiintoisimmista sivupoluista kirjassa. Suomenkin kontekstissa esimerkiksi alempaan luokkataustaan tai etnisyyteen liitetään mielikuvia vaarallisuudesta, rappiosta tai luontaisesta taipumuksesta rikollisuuteen tai päihdeongelmiin.

\section{Tarpeellisesta epämukavuudesta}

Kolmas merkittävä ulottuvuus kirjassa ovat tunteet - rakkaus, viha, nostalgia - ja kirja oli epäilemättä myös lukukokemuksena emotionaalinen. Valkoisena, transmaskuliinisena ja akateemisena lukijana oloni oli läpi koko kirjan enemmän tai vähemmän epämukava. Haritaworn ei säästele kritiikkiä tai teräväsanaisia lainauksia keittiön pöydän ääreltä kirjoittaessaan "valkoisista sukupuolentutkimusta opiskelevista queereista epäsymmetrisissä hiustyyleissään”. Tällaista epämukavuutta olisi syytä tuntea useamminkin, niin tutkijana kuin aktivistinakin. Se pakottaa lukijan kohtaamaan omat etuoikeutensa sekä pohtimaan kriittisesti niitä aktivistiprojekteja joihin mahdollisesti itse on sitoutunut. Keitä jää ulkopuolelle, ja miten itse hyödyn esimerkiksi juuri (trans)maskuliinisuudestani, akateemisesta koulutuksestani ja ihonväristäni?

Kirjassa osansa ansaitusta kritiikistä saavat myös valkoisten johtamat HLBTI-järjestöt, jotka epäonnistuvat olemaan inklusiivisia tai näkemään omaa osallisuuttaan rasististen rakenteiden ylläpitoon. Haritaworn palaa kirjassaan toistuvasti varsinkin Transgender Day of Remembrance -muistopäivään, jonka näennäisesti hyvää tarkoittava päämäärä on herättää tietoisuutta transihmisten kohtaamasta väkivallasta. TDoR sai alkunsa Yhdysvalloissa, mutta on kulkeutunut myös Eurooppaan. Eräs olennainen osa päivää on vuoden aikana surmansa saaneiden transihmisten nimien julkaiseminen. Huomionarvoista on, että muutamia poikkeuksia lukuun ottamatta nimet ovat ei-valkoisten transnaisten. Haritaworn näkeekin nimilistat materiana, valkoisten järjestöjen poliittisten päämäärien saavuttamiseksi hyödynnettävänä resurssina. Rodullistetut transnaiset hyödyttävät järjestöjä vasta kuolemansa jälkeen, ennen sitä heille ei anneta ääntä eikä heitä päästetä osallistumaan päätöksentekoon. Vain osa transihmisistä valkoiset, koulutetut, yleensä transmaskuliiniset - ansaitsee saada äänensä kuuluviin ja toimia asiantuntija-asemissa. Myös suomalaisissa TDoRtapahtumissa törmää tapaan lukea tai asettaa näkyville listoja vuoden aikana kuolleista. Kirjan valossa onkin kiinnostavaa miettiä ketä ja mitä tarkoitusta nuo listat hyödyttävät sïrtyessään maiden ja kulttuurien rajojen yli. Osallistummeko mekin etuoikeutettua ajattelemattomuuttamme vain ei-valkoisten ruumiiden kannibalistiseen hyväksikäyttöön?

Lukijana tuntuu hetkittäin aivan kuin Haritaworn haluaisi sisällyttää koko maailmanhistorian yksien kansien väliin, jokainen lause on ladattu hengästyttävällä määrällä asiaa. Hän onnistuu kuitenkin sitomaan langat yhteen helposti seurattavalla tavalla.Jäin tosin pohtimaan, tuleeko kirja hetkittäin turhaan toistaneeksi ja uudelleenrakentaneeksi kuvaamaansa vahingollista jakoa valkoisten ja ei-valkoisten ryhmien ja projektien välille.

Kirjassa kuvataan tarkkaan ja vakuuttavasti rasistiseen ja kolonialistiseen historiaan kietoutuneen queeriuden ongelmallisuutta, mutta muunlaiset mahdollisuudet tuntuvat puuttuvan. Tämä vaikuttaa myös ristiriitaiselta Haritawornin nähdäkseni peräänkuuluttaessa toisenlaisen, inklusiivisen

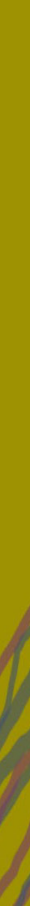


muutoksen mahdollisuutta. Dikotominen jako on kuitenkin ymmärrettävä siinä kehyksessä missä Haritaworn kirjoittaa, ja toisaalta vielä useamman haaran ja intersektionaalisen näkökulman lisääminen olisi laimentanut kritiikkiä ja hajauttanut kirjaa, joka jo nyt ulottuu niin moneen eri suuntaan.

Kirjassa kuvatut ryhmät ja prosessit kuulostavat tutuilta ja samaistuttavilta - niin hyvässä kuin pahassa - vaikka luinkin sitä eri maan kontekstissa. Joh-

tuen omasta transtutkimuksellisesta taustastani olisin kuitenkin toivonut hieman tarkempaa analyysia transsukupuolisuudesta ja sen yhteyksistä luokkaan ja valkoisuuteen liittyviin etuoikeuksiin. Erityisesti huomiot ei-valkoisten queerien sukupuolirajojen ylittämisen tulkitsemisesta yhtäaikaisesti liiallisena ja riittämättömänä olisi ansainnut vielä muutaman rivin kirjassa.

Epämukavien ja turhautuneiden, miltei epätoivoisten, tunteiden vastapainoksi haluaisin kovasti nähdä kirjan lopussa mahdollisuuden toiveikkuuteen. Loppukappaleessa Haritaworn ehdottaa, kieli poskessa, homosuukkojen käsitteellistämistä D. W. Winnicottin transitional object -käsitteen kautta. Tuttu ja turvallinen auttaa käsittelemään asioita muuttuvassa, epävarmassa poliittisessa tilanteessa. Se ei kuitenkaan ole pysyvä identiteetti, vaan väliaikainen tila, siirtymä. Siihen ei siis tarvitse jäää kiinni, vaan siitä voi päästää irti aivan kuten lapsuuden uninallesta. Haluaisin lukea tuota myös mahdollisuutena aidosti inklusiiviseen yhteistyöhön eri yhteisöjen välillä, queer-liikkeeseen, joka ei rakennu toiseuttamiselle ja rasismille. Tähän päämäärään tarvitaan juuri Queer lovers, hateful others -kirjan kaltaisia tekstejä, jotka tekevät olon epämukavaksi ja pakottavat lukijan pysähtymään ja miettimään omaa positiotaan, tutkimustaan ja aktivismiaan. 